\title{
Share repurchases in the South African mining sector
}

\author{
M. Vermeulen * \\ Department of Accountancy, Bosman Street, Stellenbosch University, \\ Private Bag X1, Stellenbosch 7600, South Africa \\ vrmeulen@sun.ac.za
}

\begin{abstract}
The purpose of this study was to obtain an overview of the share repurchase activities of companies listed in the mining sector of the JSE, and to determine the extent to which detail information of these share repurchases are available on public data sources such as SENS (Securities Exchange News Service - the office of the JSE that distributes all relevant company information electronically). The study focused on a period of 11 years, from July 1999 until the 2010 financial year-end. The annual reports of a sample of companies were analysed to determine the number of shares, as well as the monetary value of the shares that were repurchased. The SENS announcements were then scrutinised to determine the number of share repurchases recorded in the annual reports that were announced to shareholders. From a total of 55 share repurchase transactions, only 23 transactions were announced on SENS. The repurchase transactions were then further analysed in terms of the method used (general or specific repurchase), the repurchasing entity (company, subsidiary or share trust) and the subsequent sale of treasury shares from the subsidiary to the holding company. It was concluded that the majority of share repurchases are announced. However, if only companies with primary listings on the JSE are considered, $60 \%$ of share repurchases are not announced. The use of the general and specific methods are more or less equal for companies with primary listings on the JSE, but for companies with secondary listings on the JSE, 98\% of repurchases are general. Of the specific share repurchases of companies with primary listings about $46 \%$ are not announced, but of the general share repurchases about $77 \%$ are not announced. Since share repurchases made by companies with secondary listings on the JSE were significant in terms of numbers and value, it changed the total statistics substantially from what it would be if only companies with primary listing on the JSE were considered. Even though about $85 \%$ of total share repurchases are announced, studies on share repurchases cannot rely on SENS announcements only, since this would exclude a significant portion of the repurchase activities of companies with primary listings on the JSE (60\%), and therefore lead to unreliable results.
\end{abstract}

*To whom all correspondence should be addressed.

\section{Introduction}

In terms of the Companies Act 61 of 1973 (RSA, 1973) South African companies were not allowed to repurchase their own shares. This changed on 1 July 1999 with the promulgation of the Companies Amendment Act 37 of 1999 (RSA, 1999), henceforth allowing companies to repurchase their own shares. Companies now have another method, except dividends, to distribute cash to their shareholders. The use of share repurchases in South Africa got off to a slow start after 1999, in part due to uncertainty about the tax treatment of these transactions. However, once these were clarified, the use of share repurchases gained some momentum.

\section{Why use share repurchases?}

Excess cash in a company may either be retained for ongoing business operations, new investments, or paid out to shareholders in the form of dividends or share repurchases. Companies usually set a target dividend payout ratio (Baker \& Smith, 2006; Baker, Veit \& Powell, 2001; Marsh \& Merton, 1986; Lintner, 1956), which is not changed unless a higher dividend can be sustained in future. Dividends will therefore usually not be increased when there is excess cash available over the short term, since a possible dividend decrease in any subsequent year could signal a negative message to the market. Share repurchases are considered a much more flexible method to distribute excess cash to shareholders (Bhargava, 2010; Brav, Graham, Harvey \& Michaely, 2005; Jagannathan, Stephens \& Weisbach, 2000).

When distributable cash levels changes, it is easier to adjust this via share repurchases than via adjustments in dividend payments. Managers prefer avoiding to have to cut dividends and therefore increases in the dividend payout ratio are only considered after sufficient funds have been set aside for investment and liquidity requirements. The decision to repurchase shares will therefore only be considered once the investment and dividend decisions have been made (Firer, Gilbert \& Maytham, 2008; Brav et al., 2005). Share repurchases are financed from temporary cash flows while dividends are paid from sustainable cash flows (Jagannathan et al., 2000). Share repurchases are clearly more susceptible to the current financial situation of a company, and will take place on an ad hoc basis.

Companies are more likely to repurchase their own shares at times when it is difficult to find good investments (Brav et al., 2005; Grullon \& Michaely, 2004). If cash is returned to shareholders by means of share repurchases, the 
management of the company is effectively saying that it could not find a better investment opportunity for the money than that offered by the company itself (Ikenberry, Lakonishok \& Vermaelen, 1995).

Where managers believe their companies are undervalued, they may use share repurchases to increase its share prices (Brav et al., 2005; Dittmar, 2000). Share repurchases are also used as a signaling instrument, to convey to the market that managers believe the company is undervalued (Crotty, 2012a). In an efficient market, prices will adjust accordingly and this adjusted price should reflect the correct value of the company (Ikenberry et al., 1995). This market reaction, however, can only be achieved if the market is aware of the repurchase transaction. In South Africa this may prove to be a problem since not all share repurchase transactions are announced to the market.

Depending on the number of shares repurchased, the transaction can have a significant positive effect on financial ratios such as earnings per share (EPS), price-earnings ratio $(\mathrm{P} / \mathrm{E})$, return on assets (ROA), and return on equity (ROE). Managers will be totally aware of the influence of a share repurchase transaction on earnings per share (Bens, Nagar, Skinner \& Wong, 2003), since this ratio is widely used by investors to value and compare different investment options. The repurchase decision is therefore much more complicated than a mere decision to distribute extra cash flow, and managers should consider the effect it could have on the share price and relevant other financial ratios. It is clear that share repurchases are an important instrument available to managers to effectively manage cash flow and also financial performance of a company.

Research on share repurchases can provide much needed information to guide future repurchase decisions. Extensive research has been done on share repurchases internationally but not so in the South African financial environment. This study therefore aims to increase the body of knowledge available on South African share repurchases, as well as to serve as a basis for future research relating to this subject. Research on share repurchases in South African cannot be done without considering the legal framework within which these transactions take place. This determines the method used for repurchasing as well as whether these transactions are announced through SENS or not. The main source of information for this research will be the companies' annual reports and therefore a thorough understanding of the accounting treatment of these transactions is needed. The next section will give an overview of the legal environment, JSE requirements, relevant tax issues and accounting standards relating to share repurchases in South Africa, thereby setting the scene for the discussion of the current research on this topic.

\section{South African legal environment}

The Companies Amendment Act 37 of 1999 (RSA, 1999) allowed companies to repurchase their own shares as from 1 July 1999. A new act, the Companies Act 71 of 2008 (RSA,
2008), which simplifies this repurchase process substantially, was introduced recently. However, the period covered in this article (1999-2010), was still governed by the Companies Amendment Act 37 of 1999 and it will therefore be discussed firstly. Thereafter a short discussion of the relevant sections of the new act will follow.

Sections 85 to 90 of the Amendment Act determine the specific requirements for share repurchases, with the main aim of ensuring liquidity and solvency after the share repurchases have been made (Section 85(4)). There are two methods available for South African companies to repurchase shares. The first is a general repurchase, which is similar to an open market share repurchase transaction in the United States of America (USA). This method is by far the most popular in the USA, accounting for about $90 \%$ of all share repurchases (Kahle, Dyl \& Banyi, 2005). The second method is a specific repurchase and this method may be split between specific offers and pro rata offers. With a specific offer the company purchases shares from specific shareholders at a specific agreed upon price, whereas in the case of a pro rata offer, shares are bought back from all shareholders pro rata to their current shareholding. A pro rata offer may include an election option or it may be compulsory.

No share repurchases may be made without the consent of the shareholders. A special resolution (carried with a $75 \%$ majority of votes) is required to approve the repurchase of shares under a general or a specific authority (Section $85(1)$ ). The general authority to repurchase shares is valid until the next general meeting (Section 85(3)), whereas the specific authority is only valid for the specific transaction for which it was acquired.

Repurchased shares must be cancelled by the company and it will therefore reduce the issued share capital. Such shares are then restored to authorised share capital (Section 85(8)). Subsidiaries are allowed to purchase shares in their holding companies (Section 89), but these purchases are limited to a maximum of $10 \%$ of the number of issued shares. These shares are not cancelled as issued shares by the holding company since they are held by another legal entity in the group of companies.

In terms of the new Companies Act 71 of 2008 (RSA, 2008), which came into effect on 1 May 2011, the repurchase of company shares falls within the definition of a "distribution" in Section 1. The board of directors has the sole authority to decide on such distributions, thus rendering the need for shareholder approval for share repurchases unnecessary. All distributions must comply with Section 46 , which requires that the company shall pass the solvency and liquidity test, as set out in Section 4.

Section 48 contains the procedures for a company to reacquire its own shares, and describes the requirements that must be met before any repurchases may be made, as follows: 
- The board of directors must approve the repurchase (Section 48(2)(a).

- The company must pass the solvency and liquidity test.

- After the repurchase, the issued capital may not be held by subsidiaries only and may not consist of only convertible or redeemable shares (Section 48(3)).

- Repurchased shares are cancelled and restored to authorised share capital (Section 35(5)).

Section 48 also allows a subsidiary to acquire shares in its holding company, limited to $10 \%$ in total (held by all subsidiaries) of each class of shares. This provision is essentially the same as that which appeared in the 1999 Act.

\section{JSE requirements}

The listing requirements of the JSE (JSE, 2010) prescribe additional requirements that must be met before companies are allowed to repurchase their own shares. A few of the more important requirements are listed below. Those pertaining to documents which have to be submitted to the JSE will not be discussed since they have no impact on the outcome of this study.

\section{General repurchases}

- A company's articles must allow for general repurchases and also that a special resolution from the shareholders is required (Section 5.72(b,c).

- The general authority to repurchase shares, granted by shareholders at the annual general meeting, will only be valid until the company's next annual general meeting or for 15 months from the date the authority was granted, whichever period is shorter (Section 5.67(b)).

- A company may not repurchase more than a total of $20 \%$ of any class of its issued share capital in any one financial year (Section 5.68).

- The maximum price at which a company may repurchase shares is $10 \%$ above the weighted average of the market value of the share for the five business days prior to the repurchase date (Section 5.72(d)).

- As soon as a company has cumulatively repurchased $3 \%$ of the original number of shares in issue at the time that the general authority from shareholders was granted, and for each 3\% in aggregate of the original number of shares acquired after the first 3\%, it must make a SENS announcement regarding the prescribed holdings.

\section{Specific repurchases}

The following requirements for making specific repurchases pertain to both specific offers (shareholders specifically identified) and pro rata offers (to all shareholders pro rata according to their existing shareholding):

- A company's articles must allow such a repurchase and also that a special resolution from the shareholders is required (Section 5.69).
- The specific authority to repurchase shares, granted by shareholders at a general meeting, will only be valid until it is amended or revoked by means of a special resolution (Section 5.67(a)).

- As soon as a company has determined the terms of a repurchase, it should make a SENS announcement accordingly.

- A company must pursue the proposal to repurchase its shares after the announcement has been made, unless permission is granted by the JSE not to do so (Section $5.69(\mathrm{~g}))$.

The requirement to announce repurchases over 3\% has generally been interpreted as 3\% per year (Crotty, 2012b), with the effect that companies could repurchase just below $3 \%$ each year without having to announce the repurchase transaction.

\section{Tax issues}

In terms of the Income Tax Act 58 of 1962, a dividend is any amount paid by a company to its shareholders. Secondary tax on companies (STC) is payable by the company on its declared dividend, (RSA, 1962; Stiglingh, Koekemoer, Van Schalkwyk, Wilcocks, De Swardt \& Jordaan, 2011) for the period covered by this study. If shares are repurchased by a company in terms of section 85 of the Companies Act 61 of 1973, the amount above the nominal value of the shares is considered to be a dividend. A reduction in the nominal value of shares is not a dividend, unless there are profits capitalised into equity. In this case, the profits will constitute a dividend. If the same amount is therefore to be returned to shareholders as either a dividend or a share repurchase, the STC expense on the dividend will be higher than in the case of a share repurchase.

Taxes are however of secondary importance for management in the decision-making process of whether to increase dividends or to distribute excess cash in the form of share repurchases (Firer et al., 2008).

\section{Accounting standards}

The two accounting standards dealing with the disclosure of repurchased shares, are IAS 1 Presentation of financial statements (IASB, 2009a) and IAS 32 Financial instruments: Presentation (IASB, 2009b). There are a few sections in these standards that need some clarification and these are subsequently discussed below.

\section{IAS 1}

In terms of paragraph 79(a)(iv) of IAS 1, financial statements must contain a reconciliation of the opening and closing balances of the number of shares for every class of share capital. It is not clear whether this paragraph refers to the number of company shares, group shares or both (Hamman \& Wesson, 2011). 
IAS 1 paragraph 79(a)(vi) requires the disclosure of shares in the company that are held by the company itself, subsidiaries or associates, i.e. treasury shares. It is not clear whether this paragraph implies that paragraph 79(a)(iv) should be applied to treasury shares also, and therefore whether the movement in the number of treasury shares should be disclosed. It is also not clear if a distinction should be made between shares held by subsidiaries and shares held by share trusts (Hamman \& Wesson, 2011).

\section{IAS 32}

In terms of paragraph 33 of IAS 32, equity instruments that are reacquired by an entity itself, subsidiaries or any other entity in the group (called treasury shares), must be deducted from equity. The reference to other entities in the group would therefore include share trusts in the South African context. Although share repurchases by share trusts are not specifically addressed in the Companies Act or the JSE listing requirements, these repurchases constitutes a substantial portion of the total repurchase activities in South Africa. Before 2004 it was not clear how share trusts should be treated in a consolidation, since none of the Companies Act, JSE listing requirements or accounting standards made direct mention of share trusts explicitly. The consolidation principles in IAS 27 Consolidated and separate financial statements should however have led to the consolidation of share trusts, even though they were not specifically mentioned (Wainer, 2004). In 2004 the JSE cleared up this uncertainty by issuing a notice requiring all listed companies to consolidate the share trusts over which they had control for financial periods ending on or after 31 March 2004.

IAS 32 paragraph 34 refers back to IAS 1 paragraph 79(a)(vi) and requires the 'amount' of treasury shares to be disclosed in the statement of financial position or in the notes to the financial statements. IAS 1 paragraph 79(a)(vi) does not specify whether the word 'amount' refers to the number of shares, the rand amount of the shares, or both. IAS 32 paragraph 34, however, makes it clear that the rand amount of the shares should be disclosed. This raises the question whether IAS 1 paragraph 79(a)(vi) then only requires disclosure of the rand amount, or does the word 'amount' implies that the number of treasury shares should also be disclosed (Hamman \& Wesson, 2011)?

International Financial Reporting Standards (IFRS) are used in South Africa and set by the International Accounting Standards Board (IASB) in the United Kingdom (UK). In the UK, shares repurchased by the company itself do not have to be cancelled, and can be kept as treasury shares to be reissued at a later stage (Cassim, 2003). Subsidiaries and share trusts are not allowed to purchase shares in their holding companies (Bhana, 2006). In South Africa, however, subsidiaries and share trusts are allowed to purchase shares in their holding companies. Also, shares repurchased by the company itself must be cancelled, delisted and restored to authorised capital (RSA, 1999, Section 85(8)). Therefore, treasury shares in the UK refer to shares repurchased by the holding company, whereas in
South Africa treasury shares refer to shares in the holding company held by subsidiaries and share trusts in the group. Since the accounting standards were set with the UK version of treasury shares in mind, they do not address all the issues regarding the disclosure of treasury shares in South Africa, especially with regard to share incentive trusts. The result of this is that share trust transactions in South Africa are generally not disclosed in detail, making it impossible to identify the specific transactions that took place during the year. The only available information therefore is the net movement in shares held by share trusts from year to year. In most cases this movement is not even disclosed, and should be calculated by hand from the financial statements, making research on these share trust transactions almost impossible.

\section{Literature review}

The first research on share repurchases in South Africa was done by Daly (2002). He investigated repurchase activities between July 1999 and September 2001, but only included announced, general repurchases. This excluded all purchases that did not exceed the $3 \%$ cumulative threshold, as well as any specific repurchases during this period. He found that there was some uncertainty regarding the tax treatment of share repurchases since it was a new concept in South Africa at the time. Once these uncertainties were clarified, many companies introduced this method to distribute cash to their shareholders. The total value of share repurchases during this time amounted toR6.3 billion. These repurchases were made by 45 different companies via 88 SENS announcements, but this could be significantly understated, since it only included the announced, general repurchases.

Further research on South African share repurchases was published by Bhana (2007), but, again, this study only included announced, general repurchases. This research covered the period from October 2000 to March 2003 and found that 117 announcements were made. However, the sample consisted of announcements of intention to repurchase, and with general repurchases there is no obligation to actually make the repurchase. It is therefore difficult to estimate the value of actual share repurchases made during this period, based on Bhana's sample.

Bester (2008) found that there were 312 announcements made for share repurchases worth R47.2 billion from July 1999 to June 2007. This indicates that repurchase activity in South Africa gained some momentum after the initial slow start. Bester's research was an improvement on the previous research since he included specific repurchases. He, however, in turn excluded share trust repurchases and shares purchased by holding companies from their subsidiaries.

Chivaka, Siddle, Bayne, Cairney and Shev (2009) used a sample of 55 specific repurchase announcements to determine the reasons for these repurchases, as stated by the directors. The announcements were made between July 1999 and the end of 2004. They found that the three main reasons cited by directors were: enhancement of 
shareholder value, changes in shareholding, and control and administrative issues. They concluded that for all factual reasons given, practice is in line with theory.

Bester, Wesson and Hamman (2010) identified as a major problem the fact that most research omits unannounced share repurchases, since this excludes a potentially very large portion of repurchase activities. To determine the implication of this omission, they used a sample of 33 JSElisted companies for the period from July 1999 to the 2008 financial year-end to analyse all share repurchases made. They found that $59 \%$ of the total number of shares repurchased with a general authority were not announced via SENS. This amounted to $49.3 \%$ of the value of the total number of share repurchases. This effectively means that previous research dealt with only about half of the total share repurchases in South Africa. It will be difficult to do further research on share repurchases in South Africa since existing data sources do not include unannounced share repurchases.

Furthermore, general repurchases account for $47.9 \%$ of the total number of shares repurchased and roughly $60.5 \%$ of the total value thereof. This will lead to a material understatement of the total share repurchases if specific repurchases are not taken into account (Bester et al., 2010). Their study also analysed the number of shares repurchased based on the repurchasing entity and found the following: $26.1 \%$ are repurchased by the company, not including treasury shares purchased from a subsidiary (17.1\%), and $56.8 \%$ are repurchased by subsidiaries (these figures exclude purchases by share trusts).

Research on share repurchases in South Africa is further complicated by the fact that the company itself, its subsidiaries or share incentive trusts, are allowed to repurchase shares. Treasury shares may also be sold back to the holding company at a later stage, or to any other party within or outside the group. The effect of treasury shares should therefore be considered in all share repurchase research.

With regard to the disclosure of share repurchases in South Africa, Hamman and Wesson (2011) found that JSE-listed companies interpret the disclosure requirements significantly differently. The number of group shares is not applied in the same way by all companies as a result of the uncertainties surrounding the requirements of IAS 1. The number of group shares is used in performance calculations such as earnings per share, net asset value per share and market capitalisation and should therefore be calculated and disclosed in the same way by all listed companies. This is important to protect the users of financial statements. Treasury shares held by subsidiaries and share trusts are also not disclosed consistently in company financial statements, making it extremely difficult to calculate the number of group shares for some companies (Bester et al., 2010). These issues should be addressed by financial managers when preparing financial statements. Better disclosure of the movement in company, group and trust shares could lead to better research in this field, providing valuable information for better decision-making.

No previous research has been done specifically on the mining sector in South Africa. In South Africa mining companies are a major contributor to economic activity. Companies listed in the mining sector constitute roughly $17 \%$ of the total number of listed companies on the JSE. In terms of size, measured by market capitalisation, companies in the mining sector constitute roughly $27 \%$ of the total market capitalisation of the JSE (calculated from a list of the market capitalisations of all listed companies on 7 October 2011 - requested by the authors from the JSE directly). Current research on share repurchases in South Africa therefore excludes a significant portion of the market, and thus could also be excluding a large proportion of repurchase activities.

\section{Research objective}

The aim of this research is to determine the extent of share repurchases of JSE-listed South African companies in the mining sector, taking cognisance of the above mentioned constraints. This research will also attempt to determine if SENS announcements only are a reliable source for studies on share repurchases. The data gathered on share repurchases in the mining sector will then be available for use in future research on share repurchases such as buy-andhold and event studies. By including share repurchases, specifically from the mining sector, in future research will lead to more representative samples and a more complete picture of repurchase activities in South Africa.

\section{Research methodology}

None of the financial data sources in South Africa (McGregor BFA, I-Net Bridge and Reuters) has detailed records available on share repurchases. It is therefore impossible to use these sources to obtain a complete picture of the repurchase activities for mining companies in South Africa. It was decided to use the same labour-intensive approach adopted by Bester et al. (2010), which involved analysing the annual reports for all companies in the sample from 1999 to 2010 and investigating all changes in the issued share capital. This approach identifies company share repurchases and cancellation of shares, share repurchases and subsequent sales by subsidiaries, as well as share transactions with consolidated share trusts, using directors' reports, statements of financial position, statements of changes in equity and share capital notes as the main sources of information.

Furthermore, the SENS announcements of companies' repurchase activities were also obtained from the McGregor BFA news service. All JSE SENS announcements are stored in this database and can be retrieved using a keyword search. The keywords used were: "repurchase", "buy-back", "buy back", "buyback" and "treasury". These announcements were compared with the repurchase information obtained from the annual reports. Since SENS 
announcements only need to be made for specific repurchases and general repurchases exceeding 3\% of the issued shares, the data obtained from SENS announcements only represent a portion of the total repurchase activities.

The information gathered from SENS and the annual reports was used to determine the extent of share repurchases in the mining sector. Share repurchases were analysed according to the repurchasing entity, being either the company itself, subsidiaries or share trusts. Share repurchases by the company were split between purchases from subsidiaries and from other shareholders. Treasury shares subsequently sold by subsidiaries (to either the holding company or other shareholders) were also noted. For all repurchase transactions, the number of shares as well as the monetary values were obtained from the data sources.

The data was analysed and compared to the results of the Bester et al. (2010) study, in order to determine the extent and nature of share repurchase transactions in the mining sector, compared to the rest of the market.

\section{Sample selection}

The sample includes all companies listed in the mining sector on 31 December 2010. Companies with secondary listings on the JSE were included in the sample even though they are not subjected to the JSE listing requirements. Their results were summarised separately since they are allowed to hold their own shares as treasury shares (Cassim, 2003), which is not allowed for South African companies. Three companies (Sephaku Holdings Ltd; Trans Hex Group Ltd; White Water Resources Ltd) were excluded from the sample because of improper disclosure in their financial statements which made it impossible to determine the number and/or value of share repurchases. Randgold and Exploration Company Ltd has a primary listing on the JSE, but was left out of the sample because it incorrectly treated its share buyback according to the listing requirements of the Nasdaq Stock Market, where it has its secondary listing. The market capitalisation of the four companies that were excluded from the sample constitute less than $0.02 \%$ of the total market capitalisation at the time of sample selection. Please refer to Appendix A for a list of the companies which were included in the sample.

\section{Results}

For the period under review (July 1999 until financial yearend 2010), Table 1 illustrates that 13 companies made 23 repurchase announcements via SENS. These announcements include 17 general and six specific repurchases. For the purposes of this tabulation, all the share repurchases made during a particular financial year were counted as one repurchase activity.

It was found that in total 19 companies undertook 55 repurchasing activities during the period under review. The above mentioned number includes both announced and unannounced repurchases. Of these repurchases 44 were general and 11 were specific repurchases. It is therefore clear that general repurchases are favoured above specific repurchases, and that approximately $60 \%$ (in terms of number of transactions) of repurchase activities were not announced via SENS. These 55 repurchase activities were consequently analysed further in terms of number of shares as well as monetary value to provide a clearer picture of the total repurchase activity.

Tables 2 to 6 show the repurchase activities of companies with primary and secondary listings on the JSE separately, as well as the total repurchase activities for all companies. The companies with secondary listings that repurchased shares during the period under review are Anglo American Plc, Aquarius Platinum Ltd, BHP Billiton Plc and Lonmin Plc. The financial statements of the above mentioned companies are presented in US Dollar. Where the exact date of the repurchase was reported, the exchange rate on that day was used to convert the value of the transaction to SA Rand. In all other cases the exchange rate at year end was used.

Table 2 shows the total general repurchases, split between announced and unannounced repurchases in terms of the number of shares as well as the monetary values.

A total of 87.9 million shares were repurchased under general authority by companies with a primary listing. This represents a total value of R3.3 billion. In comparison, companies with a secondary listing repurchased 958.9 million shares for a total value of R170.7 billion.

In respect of the companies with a primary listing, approximately three quarters $(76.6 \%)$ of the total repurchase transactions under general authority were not announced via SENS, but in value terms they represent only $41.7 \%$ of the total amount. These general repurchases were made by 14 of the 15 repurchasing companies. The $15^{\text {th }}$ company made only a specific repurchase during the target period.

In respect of the companies with a secondary listing, only $5.8 \%$ of general repurchases were not announced, representing only $0.5 \%$ of the value of general repurchases. It is clear that the companies with listings on international stock exchanges are more inclined to announce their repurchase transactions.

In terms of number of shares the percentage of announced repurchases increases from $23.4 \%$ for primary listings only, to a total of $88.3 \%$ when the secondary listings are taken into account. Of the total value of R174 billion worth of general repurchases, $98.7 \%$ were announced.

Table 3 compares the general repurchases to the specific repurchases. It also indicates how much of the specific repurchases were treasury shares repurchased by the holding companies from subsidiaries. 
Table 1: Companies included in study

\begin{tabular}{|c|c|c|c|c|c|c|c|}
\hline \multirow[b]{2}{*}{ No. } & \multirow[b]{2}{*}{ Company name } & \multicolumn{3}{|c|}{ SENS Announcements } & \multicolumn{3}{|c|}{ Repurchases (annual) } \\
\hline & & Total & General & Specific & Total & General & Specific \\
\hline 1 & African Rainbow Minerals Ltd & 0 & 0 & 0 & 0 & 0 & 0 \\
\hline 2 & Anglo American Plc * & 3 & 3 & 0 & 3 & 3 & 0 \\
\hline 3 & Anglo Platinum Ltd & 2 & 2 & 0 & 2 & 2 & 0 \\
\hline 4 & Anglogold Ashanti Ltd & 0 & 0 & 0 & 0 & 0 & 0 \\
\hline 5 & Anooraq Resources Corporation & 0 & 0 & 0 & 0 & 0 & 0 \\
\hline 6 & Aquarius Platinum Ltd * & 1 & 0 & 1 & 2 & 1 & 1 \\
\hline 7 & Assore Ltd & 1 & 0 & 1 & 8 & 5 & 3 \\
\hline 8 & Bauba Platinum Ltd & 0 & 0 & 0 & 0 & 0 & 0 \\
\hline 9 & BHP Billiton Plc* & 6 & 6 & 0 & 8 & 8 & 0 \\
\hline 10 & BRC Diamond Core Ltd * & 0 & 0 & 0 & 0 & 0 & 0 \\
\hline 11 & Central Rand Gold Ltd * & 0 & 0 & 0 & 0 & 0 & 0 \\
\hline 12 & Chrometco Ltd & 1 & 0 & 1 & 2 & 1 & 1 \\
\hline 13 & Coal of Africa Ltd * & 0 & 0 & 0 & 0 & 0 & 0 \\
\hline 14 & Diamondcorp Plc* & 0 & 0 & 0 & 0 & 0 & 0 \\
\hline 15 & Drdgold Ltd & 0 & 0 & 0 & 0 & 0 & 0 \\
\hline 16 & Eastern Platinum Ltd * & 0 & 0 & 0 & 0 & 0 & 0 \\
\hline 17 & Exxaro Resources Ltd & 2 & 0 & 2 & 3 & 1 & 2 \\
\hline 18 & Firestone Energy Ltd & 0 & 0 & 0 & 0 & 0 & 0 \\
\hline 19 & Gold Fields Ltd & 0 & 0 & 0 & 1 & 1 & 0 \\
\hline 20 & Gold One International Ltd * & 0 & 0 & 0 & 0 & 0 & 0 \\
\hline 21 & Great Basin Gold Ltd * & 0 & 0 & 0 & 0 & 0 & 0 \\
\hline 22 & Harmony Gold Mining Company Ltd & 0 & 0 & 0 & 0 & 0 & 0 \\
\hline 23 & Hwange Colliery Company Ltd* & 0 & 0 & 0 & 0 & 0 & 0 \\
\hline 24 & Impala Platinum Holdings Ltd & 1 & 1 & 0 & 3 & 3 & 0 \\
\hline 25 & Infrasors Holdings Ltd & 1 & 1 & 0 & 3 & 3 & 0 \\
\hline 26 & JCI Ltd & 0 & 0 & 0 & 3 & 3 & 0 \\
\hline 27 & Jubilee Platinum Plc & 0 & 0 & 0 & 0 & 0 & 0 \\
\hline 28 & Keaton Energy Holdings Ltd & 0 & 0 & 0 & 0 & 0 & 0 \\
\hline 29 & Lonmin Plc * & 2 & 2 & 0 & 2 & 2 & 0 \\
\hline 30 & Merafe Resources Ltd & 0 & 0 & 0 & 0 & 0 & 0 \\
\hline 31 & Miranda Mineral Holdings Ltd & 1 & 1 & 0 & 1 & 1 & 0 \\
\hline 32 & Mvelaphanda Resources Ltd & 0 & 0 & 0 & 1 & 1 & 0 \\
\hline 33 & Northam Platinum Ltd & 0 & 0 & 0 & 0 & 0 & 0 \\
\hline 34 & Optimum Coal Holdings Ltd & 0 & 0 & 0 & 0 & 0 & 0 \\
\hline 35 & Pamodzi Gold Ltd & 0 & 0 & 0 & 0 & 0 & 0 \\
\hline 36 & Pan African Resources Plc * & 0 & 0 & 0 & 0 & 0 & 0 \\
\hline 37 & Petmin Ltd & 0 & 0 & 0 & 5 & 3 & 2 \\
\hline 38 & Platfields Ltd & 0 & 0 & 0 & 0 & 0 & 0 \\
\hline 39 & Platmin Ltd * & 0 & 0 & 0 & 0 & 0 & 0 \\
\hline 40 & Resources Generation Ltd * & 0 & 0 & 0 & 0 & 0 & 0 \\
\hline 41 & Rockwell Diamonds Incorporated * & 0 & 0 & 0 & 0 & 0 & 0 \\
\hline 42 & Royal Bafokeng Platinum Ltd & 0 & 0 & 0 & 0 & 0 & 0 \\
\hline 43 & Sallies Ltd & 0 & 0 & 0 & 0 & 0 & 0 \\
\hline 44 & Sentula Mining Ltd & 1 & 0 & 1 & 5 & 4 & 1 \\
\hline 45 & Simmer and Jack Mines Ltd & 0 & 0 & 0 & 0 & 0 & 0 \\
\hline 46 & South African Coal Mining Holdings Ltd & 0 & 0 & 0 & 1 & 0 & 1 \\
\hline 47 & Tawana Resources N1 * & 0 & 0 & 0 & 0 & 0 & 0 \\
\hline 48 & Thabex Ltd & 0 & 0 & 0 & 1 & 1 & 0 \\
\hline 49 & Uranium One Inc * & 0 & 0 & 0 & 0 & 0 & 0 \\
\hline 50 & Village Main Reef Gold Min Comp Ltd & 0 & 0 & 0 & 0 & 0 & 0 \\
\hline 51 & Wescoal Holdings Ltd & 1 & 1 & 0 & 1 & 1 & 0 \\
\hline 52 & Wesizwe Platinum Ltd & 0 & 0 & 0 & 0 & 0 & 0 \\
\hline \multirow[t]{2}{*}{53} & Witwatersrand Cons Gold Resources & 0 & 0 & 0 & 0 & 0 & 0 \\
\hline & * Secondary listing on JSE & 23 & 17 & 6 & 55 & 44 & 11 \\
\hline
\end{tabular}


Table 2: Share purchases under general authority

\begin{tabular}{|c|c|c|c|c|}
\hline TOTAL & Number & $\%$ & Rand & $\%$ \\
\hline Announced buy-backs & 923780193 & 88.3 & 171827674347 & 98.7 \\
\hline Unannounced buy-backs & 122984681 & 11.7 & 2178814162 & 1.3 \\
\hline Total buy-backs under general authority & 1046764874 & 100 & 174006488509 & 100 \\
\hline RSA - Primary listings & Number & $\%$ & Rand & $\%$ \\
\hline Announced buy-backs & 20584200 & 23.4 & 1932924921 & 58.3 \\
\hline Unannounced buy-backs & 67300504 & 76.6 & 1383404612 & 41.7 \\
\hline Total buy-backs under general authority & 87884704 & 100 & 3316329533 & 100 \\
\hline RSA - Secondary listings & Number & $\%$ & Rand & $\%$ \\
\hline Announced buy-backs & 903195993 & 94.2 & 169894749426 & 99.5 \\
\hline Unannounced buy-backs & 55684177 & 5.8 & 795409550 & 0.5 \\
\hline Total buy-backs under general authority & 958880170 & 100 & 170690158976 & 100 \\
\hline
\end{tabular}

Table 3: Share buy backs: Specific versus general authority

\begin{tabular}{|c|c|c|c|c|}
\hline TOTAL & Number & $\%$ & Rand & $\%$ \\
\hline Buy-backs under specific authority & 123401076 & 10.5 & 7617980342 & 4.2 \\
\hline $\begin{array}{l}\text { Treasury shares purchased } \\
\text { from subsidiary } \\
\text { Other }\end{array}$ & $\begin{array}{r}21687765 \\
101713311\end{array}$ & & $\begin{array}{r}778677686 \\
6839302656\end{array}$ & \\
\hline Buy-backs under general authority & 1046764874 & 89.5 & 174006488509 & 95.8 \\
\hline Total share buy-backs & 1170165950 & 100 & 181624468851 & 100 \\
\hline RSA - Primary listings & Number & $\%$ & Rand & $\%$ \\
\hline Buy-backs under specific authority & 101975178 & 53.7 & 5362848873 & 61.8 \\
\hline $\begin{array}{l}\text { Treasury shares purchased } \\
\text { from subsidiary } \\
\text { Other }\end{array}$ & $\begin{array}{l}21687765 \\
80287413\end{array}$ & & $\begin{array}{r}778677686 \\
4584171187\end{array}$ & \\
\hline Buy-backs under general authority & 87884704 & 46.3 & 3316329533 & 38.2 \\
\hline Total share buy-backs & 189859882 & 100 & 8679178406 & 100 \\
\hline RSA - Secondary listings & Number & $\%$ & Rand & $\%$ \\
\hline Buy-backs under specific authority & 21425898 & 2.2 & 2255131469 & 1.3 \\
\hline $\begin{array}{l}\text { Treasury shares purchased } \\
\text { from subsidiary } \\
\text { Other }\end{array}$ & 21425898 & & 2255131469 & \\
\hline Buy-backs under general authority & 958880170 & 97.8 & 170690158976 & 98.7 \\
\hline Total share buy-backs & 980306068 & 100 & 172945290445 & 100 \\
\hline
\end{tabular}

Table 3 shows that 189.9 million shares, with a total value of R8.7 billion, were repurchased by the 15 companies with primary listings during the period under review. The four companies with secondary listings repurchased 980.3 million shares, with a total value of R172.9 billion. This brings the total repurchases to 1.2 billion shares with a value of R181.6 billion.

Of these shares, $89.5 \%$ were repurchased under general authority in terms of number of shares, which represented $95.8 \%$ in value. The remaining $10.5 \%$ of the total number of shares repurchased, representing $4.2 \%$ of the total value, were repurchased under specific authority. The fact that almost $90 \%$ of repurchases were under general authority can be largely attributed to the fact that the companies with secondary listings used general repurchases to distribute cash to their shareholders. Of the 15 repurchase transactions by companies with secondary listings, only 1 was a specific repurchase - representing only $1.3 \%$ of the total value of repurchases made.

Table 4 shows the total number of actual shares that were repurchased according to the repurchasing entity. 
Table 4: Share buy backs by repurchasing entity

\begin{tabular}{|c|c|c|c|c|c|}
\hline TOTAL & Number & $\%$ & Rand & $\%$ & Number \\
\hline Company own shares repurchased and cancelled & 839233018 & 57.9 & 71.7 & 95781515673 & 52.7 \\
\hline $\begin{array}{l}\text { Company own shares repurchased and held as } \\
\text { treasury }\end{array}$ & 55959430 & 3.9 & 4.8 & 35356910000 & 19.5 \\
\hline Subsidiary purchases & 253285737 & 17.5 & 21.6 & 49707365492 & 27.4 \\
\hline Subtotal & 1148478185 & 79.3 & 98.1 & 180845791165 & $\overline{99.6}$ \\
\hline Company repurchases shares from subsidiary & 21687765 & 1.5 & 1.9 & 778677686 & 0.4 \\
\hline Repurchases excluding share trusts & 1170165950 & 80.8 & 100 & 181624468851 & 100 \\
\hline Share trusts consolidated & 278544777 & 19.2 & & & \\
\hline Total share buy-backs & 1448710727 & 100 & & & \\
\hline
\end{tabular}

\begin{tabular}{|c|c|c|c|c|c|}
\hline RSA - Primary listings & Number & $\%$ & Rand & $\%$ & Number \\
\hline Company own shares repurchased & 86760686 & 18.6 & 45.7 & 3143834778 & 36.2 \\
\hline Subsidiary purchases & 81411431 & 17.4 & 42.9 & 4756665942 & 54.8 \\
\hline Subtotal & 168172117 & 36.0 & 88.6 & 7900500720 & 91.0 \\
\hline Company repurchases shares from subsidiary & 21687765 & 4.6 & 11.4 & 778677686 & 9.0 \\
\hline Repurchases excluding share trusts & 189859882 & 40.6 & 100 & 8679178406 & 100 \\
\hline Share trusts consolidated & 277303858 & 59.4 & & & \\
\hline Total share buy-backs & 467163740 & 100 & & & \\
\hline
\end{tabular}

\begin{tabular}{|c|c|c|c|c|c|}
\hline RSA - Secondary listings & Number & $\%$ & Rand & $\%$ & Number \\
\hline Company own shares repurchased and cancelled & 752472332 & 76.7 & 76.8 & 92637680895 & 53.6 \\
\hline $\begin{array}{l}\text { Company own shares repurchased and held as } \\
\text { treasury }\end{array}$ & 55959430 & 5.7 & 5.7 & 35356910000 & 20.4 \\
\hline Subsidiary purchases & 171874306 & 17.5 & 17.5 & 44950699550 & 26.0 \\
\hline Repurchases excluding share trusts & 980306068 & 99.9 & 100 & 172945290445 & 100 \\
\hline Share trusts consolidated & 1240919 & 0.1 & & & \\
\hline Total share buy-backs & 981546987 & 100 & & & \\
\hline
\end{tabular}

For the companies with primary listings on the JSE, more than half of the total share repurchases (59.4\%) represent share trust consolidations. In total, 467 million shares, including share trust consolidations, were repurchased, of which $18.6 \%$ were initially repurchased by the company and $17.4 \%$ by subsidiaries of the parent company. Subsequently, the company repurchased $4.6 \%$ from the subsidiaries. When the share trust consolidations are excluded from the buyback activities, it shows that only 189.9 million shares were repurchased, which can further be explained as follows: $45.7 \%$ of the shares were initially repurchased by the company, $42.9 \%$ represents shares repurchased by subsidiaries, and $11.4 \%$ were subsequently repurchased by the company from the subsidiary. When expressed in terms of value, these repurchases represent an amount of R8.7 billion, which comprises $36.2 \%, 54.8 \%$ and $9.0 \%$ of the repurchasing entities, respectively. Repurchases by share trusts were excluded from further analysis owing to lack of proper disclosure of share transactions with share trusts (refer to the section on accounting standards).

The repurchasing companies with secondary listings on the JSE have their primary listings in the UK and Australia. In these countries companies are allowed to repurchase their own shares and keep them as treasury shares. These shares may then be reissued by the company, or cancelled at a later stage. The number of such shares repurchased and held by the company during the period under review is 55.9 million with a total value of R35.3 billion, constituting $20.4 \%$ of the value of all repurchases made.

The majority of all share repurchase are made by the company itself, with the shares subsequently being cancelled $(71.7 \%$ when not taking into account share trust transactions). When excluding companies with secondary listings from this figure, the repurchases are more evenly spread between the company itself and its subsidiaries.

Table 5 shows that of the total share repurchases of 189.9 million shares, by the companies with primary listings, $39.7 \%$ (79.5\% in terms of value) were announced via SENS and $60.3 \%(20.5 \%$ in terms of value $)$ were unannounced. For the 980.3 million shares repurchased by the companies with secondary listings, $94.3 \%$ (99.5\% in terms of value) were announced via SENS and only $5.7 \%$ $(0.5 \%$ in terms of value) were unannounced. The difference is quite significant, with the internationally listed companies being much more transparent regarding their share transactions. 
Table 5: Share buy backs: Announced versus unannounced

\begin{tabular}{|c|c|c|c|c|}
\hline TOTAL & Number & $\%$ & Rand & $\%$ \\
\hline Buy-backs under specific authority & 123401076 & & 7617980342 & \\
\hline Announced & 76172512 & & 7223908119 & \\
\hline Unannounced & 47228564 & & 394072223 & \\
\hline Buy-backs under general authority & 1046764874 & & 174006488509 & \\
\hline Announced & 923780193 & & 171827674347 & \\
\hline Unannounced & 122984681 & & 2178814162 & \\
\hline Total share buy-backs & 1170165950 & 100 & 181624468851 & 100 \\
\hline Announced & 999952705 & 85.5 & 179051582466 & 98.6 \\
\hline Unannounced & 170213245 & 14.5 & 2572886385 & 1.4 \\
\hline
\end{tabular}

\begin{tabular}{|c|c|c|c|c|}
\hline $\begin{array}{l}\text { RSA - Primary listings } \\
\text { Buy-backs under specific authority }\end{array}$ & $\begin{array}{l}\text { Number } \\
101975178\end{array}$ & $\%$ & $\begin{array}{l}\text { Rand } \\
5362848873\end{array}$ & $\%$ \\
\hline Announced & 54746614 & & 4968776650 & \\
\hline Unannounced & 47228564 & & 394072223 & \\
\hline Buy-backs under general authority & 87884704 & & 3316329533 & \\
\hline Announced & 20584200 & & 1932924921 & \\
\hline Unannounced & 67300504 & & 1383404612 & \\
\hline Total share buy-backs & 189859882 & 100 & 8679178406 & 100 \\
\hline Announced & 75330814 & 39.7 & 6901701571 & 79.5 \\
\hline Unannounced & 114529068 & 60.3 & 1777476835 & 20.5 \\
\hline
\end{tabular}

\begin{tabular}{|c|c|c|c|c|}
\hline RSA - Secondary listings & Number & $\%$ & Rand & $\%$ \\
\hline Buy-backs under specific authority & 21425898 & & 2255131469 & \\
\hline $\begin{array}{l}\text { Announced } \\
\text { Unannounced }\end{array}$ & 21425898 & & 2255131469 & \\
\hline Buy-backs under general authority & 958880170 & & 170690158976 & \\
\hline Announced & 903195993 & & 169894749426 & \\
\hline Unannounced & 55684177 & & 795409550 & \\
\hline Total share buy-backs & 980306068 & 100 & 172945290445 & 100 \\
\hline Announced & 924621891 & 94.3 & 172149880895 & 99.5 \\
\hline Unannounced & 55684177 & 5.7 & 795409550 & 0.5 \\
\hline
\end{tabular}

The above findings confirm the problem noted by Bester et al. (2010) that research on share repurchases in South Africa cannot be done using only the current available data sources, since they exclude unannounced share repurchases $(60.3 \%)$, which is a significant portion of total repurchase activities.

Table 6 shows that of the total number of 1.2 billion shares repurchased by the companies during the target period,

21.7 million shares were subsequently sold by the subsidiaries to their holding companies and 76.8 million shares were sold to entities not within the group. In terms of number of shares, $8.4 \%$ of the initial share repurchases were therefore subsequently sold. When looking only at the companies with primary listings, $23.5 \%$ of the treasury shares were subsequently sold.

Table 7 reveals the actual number of shares repurchased by the companies per year during the target period. From the results, it is clear that the share repurchase activities varied on a yearly basis. The highest share repurchase activity, as seen in Table 7 , was $34 \%$ in 2007 , with the lowest repurchase activity in $2004(0.4 \%)$. In terms of value, the highest share repurchase activity was also in 2007 (46.1\%), and the lowest in 2000 and $2004(0 \%)$. The reasons for the variations in repurchase activities from year to year were not within the scope of this study. 
Table 6: Share buy backs: Purchases and sales

\begin{tabular}{|c|c|c|c|c|}
\hline TOTAL & Number & $\%$ & Rand & $\%$ \\
\hline Repurchases & 1170165950 & \multirow[t]{4}{*}{100} & 181624468851 & \multirow[t]{4}{*}{100} \\
\hline Company own shares repurchased & 895192448 & & 131138425673 & \\
\hline Subsidiary purchases & 253285737 & & 49707365492 & \\
\hline Company repurchases from subsidiary & 21687765 & & 778677686 & \\
\hline Sales & -98475060 & \multirow[t]{3}{*}{8.4} & -2366251612 & \multirow[t]{3}{*}{1.3} \\
\hline Subsidiary sells to company & -21687765 & & -778677686 & \\
\hline Subsidiary sells to external parties & -76787295 & & -1587573926 & \\
\hline $\begin{array}{l}\text { Net figure for share buy-backs, excluding share trust } \\
\text { consolidations }\end{array}$ & 1071690890 & 91.6 & 179258217239 & 98.7 \\
\hline RSA - Primary listings & Number & $\%$ & Rand & $\%$ \\
\hline Repurchases & 189859882 & \multirow[t]{4}{*}{100} & 8679178406 & \multirow[t]{4}{*}{100} \\
\hline Company own shares repurchased & 86760686 & & 3143834778 & \\
\hline Subsidiary purchases & 81411431 & & 4756665942 & \\
\hline Company repurchases from subsidiary & 21687765 & & 778677686 & \\
\hline Sales & -44590658 & \multirow[t]{3}{*}{23.5} & -806491612 & \multirow[t]{3}{*}{9.3} \\
\hline Subsidiary sells to company & -21687765 & & -778677686 & \\
\hline Subsidiary sells to external parties & -22902893 & & -27813926 & \\
\hline $\begin{array}{l}\text { Net figure for share buy-backs, excluding share trust } \\
\text { consolidations }\end{array}$ & 145269224 & 76.5 & 7872686794 & 90.7 \\
\hline RSA - Secondary listings & Number & $\%$ & Rand & \multirow{5}{*}{$\begin{array}{c}\% \\
100\end{array}$} \\
\hline Repurchases & 980306068 & \multirow[t]{4}{*}{100} & 172945290445 & \\
\hline Company own shares repurchased & 808431762 & & 127994590895 & \\
\hline Subsidiary purchases & 171874306 & & 44950699550 & \\
\hline Company repurchases from subsidiary & 0 & & 0 & \\
\hline Sales & -53884402 & \multirow[t]{3}{*}{5.5} & -1559760000 & \multirow[t]{3}{*}{0.9} \\
\hline Subsidiary sells to company & 0 & & 0 & \\
\hline Subsidiary sells to external parties & -53884402 & & -1559760000 & \\
\hline $\begin{array}{l}\text { Net figure for share buy-backs, excluding share trust } \\
\text { consolidations }\end{array}$ & 926421666 & 94.5 & 171385530445 & 99.1 \\
\hline
\end{tabular}

Table 7: Share buy back activities - All companies

\begin{tabular}{|c|c|c|c|c|}
\hline Year & Number & $\%$ & Rand & $\%$ \\
\hline 1999 & 53298029 & 4.6 & 699480000 & 0.4 \\
\hline 2000 & 14694110 & 1.3 & 25947000 & 0.0 \\
\hline 2001 & 15662230 & 1.3 & 1371537407 & 0.8 \\
\hline 2002 & 32815571 & 2.8 & 1896451267 & 1.0 \\
\hline 2003 & 10060048 & 0.9 & 150371000 & 0.1 \\
\hline 2004 & 4177306 & 0.4 & 2961924 & 0.0 \\
\hline 2005 & 207709089 & 17.8 & 12559207169 & 6.9 \\
\hline 2006 & 248855396 & 21.3 & 44257964678 & 24.4 \\
\hline 2007 & 397937960 & 34.0 & 83668556000 & 46.1 \\
\hline 2008 & 136743102 & 11.7 & 35633462160 & 19.6 \\
\hline 2009 & 32013230 & 2.7 & 1024369776 & 0.6 \\
\hline 2010 & 16199879 & 1.4 & 334160470 & 0.2 \\
\hline Total share buy-backs & 1170165950 & 100 & 181624468851 & 100 \\
\hline
\end{tabular}

\section{Conclusion}

Research was conducted to investigate share repurchase activities of a sample of JSE-listed companies in the mining sector over 11 years from July 1999 until financial year-end in 2010. Initially all the companies in the mining sector were considered. Some companies were excluded from this study for the reason that there were improper disclosures in the financial statements regarding repurchases and one company was excluded due to the incorrect treatment of share repurchases. The sample eventually consisted of 53 companies, of which 19 companies undertook share repurchases based on a detailed analysis of their financial statements. Of these, only 13 companies reported their share repurchase transactions via SENS.

For the target period in the mining sector, it was found that $89.5 \%$ of the total number of shares repurchased were under 
general authority, and $10.5 \%$ of the total number of shares repurchased were under specific authority. When compared to the findings of the study by Bester et al. (2010), it was concluded that, in terms of number of shares, the split between general and specific share repurchases were significantly different. In Bester's study $47.9 \%$ of repurchases were general and $52.1 \%$ were specific. The main cause for the difference is the repurchases made by companies with secondary listings, of which only $2.2 \%$ were specific.

However, the total number of shares repurchased that were announced via SENS in this study amounted to $85.5 \%$, which is a higher percentage than the $69.1 \%$ found in the study by Bester et al. (2010). However, the companies with primary listings on the JSE announced only $39.7 \%$ of their total repurchases, much less than the $69.1 \%$ found by Bester et al. (2010). It is therefore evident that any research relating to share repurchase activities in South Africa, will be totally inaccurate and not a true reflection of actual events if it is only based on information announced via SENS.

Although no definite trends were identified in share repurchases on a year-to-year basis, the highest percentages of share repurchases in this study were recorded in the 2007 financial year, namely $34 \%$ (46.1\% in terms of value). In the study by Bester et al. (2010), the highest percentage of share repurchases were recorded in the 2006 financial year $(27.6 \%)$.

Compared to repurchase activities in the rest of the market, the repurchases of mining companies with primary listing on the JSE are relatively low, in terms of number of transactions, number of shares as well as in the monetary value of shares. However, if the repurchase activities of companies with secondary listings on the JSE are added, the number of shares repurchased increase from 190 million to 1.2 billion, and the monetary value of these transactions increase from R8.7 billion to R181.6 billion. The total number of shares repurchased noted by Bester et al. (2010) was 2.3 billion, with a total value of R52.1 billion. Share repurchases in the mining sector is therefore more than triple the value of share repurchase in the rest of the market, and can therefore not be ignored in studies regarding share repurchase activities.

\section{Managerial implications and recommendations for future research}

Share repurchases are an effective method to distribute cash to shareholders and could have a significant impact on the financial performance of a company. The repurchase transaction could also be used to signal information to the market, but then these repurchases should be announced. If a company is undervalued and managers elect to repurchase shares, but the transaction is not announced, the positive effect it could have on the share price is diminished. Also, if shareholders are not aware of a share repurchases program, they are making decisions about their investment without having all the necessary information. From this research it is clear that a significant portion of repurchases in South Africa is not announced. Most companies are therefore not using repurchases to its full potential in terms of the effect on share price and valuation models. Much more could be gained from repurchase transactions if the effect thereof in the South African market is better researched and documented. This is indeed a dynamic management and financial mechanism and further research is imperative for the investment environment. Proper research however, demands much more detailed disclosures from the respective companies. Recently the JSE released a proposal to require better disclosure of share repurchases in annual reports, which has been welcomed by investors and academics alike (Crotty, 2012b). This should lead to better disclosure in future, creating many opportunities for valueadding research. In depth studies and focused research will empower researchers to provide useful and valuable results to the management structures of the companies involved.

Future studies can also investigate the impact that share repurchases have on the trend of dividend payout ratios, if any. Buy-and-hold analyses could also be undertaken to determine the long term effect of a repurchase transaction on the relevant company's share price.

As noted before, the legal requirements for share repurchases were simplified with the new Companies Act. It will be interesting to note whether the simplified requirements will indeed lead to an increase in share repurchases in South Africa over the next few years. This is also a valuable research item for future legislative adjustments in this dynamic financial arena.

\section{References}

Baker, H.K. \& Smith, D.M. 2006. 'In search of a residual dividend policy', Review of Financial Economics, 15: 1-18.

Baker, H.K., Veit, E.T. \& Powell, G.E. 2001. 'Factors influencing dividend policy decisions of Nasdaq firms', The Financial Review, 38: 19-38.

Bens, D., Nagar, V., Skinner, D.J. \& Wong, M.H.F. 2003. 'Employee stock options, EPS dilution, and stock repurchases', Journal of Accounting and Economics, 36: 5190 .

Bester, P.G. 2008. 'Shareholder distribution choices for industrial companies listed on the JSE: Share buybacks vs. dividends'. Unpublished MBA research report, University of Stellenbosch, Bellville.

Bester, P.G., Wesson, N. \& Hamman, W.D. 2010. 'Share buy-backs for a selection of JSE listed companies: An exploratory study', South African Journal of Business Management, 41(4): 47-58.

Bhana, D. 2006. 'The company law implications of conferring a power on a subsidiary to acquire the shares of 
its holding company', Stellenbosch Law Review, 17(2): 232250 .

Bhana, N. 2007. 'The market reaction to open market share repurchases announcement: The South African experience', Investment Analysts Journal, 65: 25-36.

Bhargava, A. 2010. 'An econometric analysis of dividends and share repurchases by US firms', Journal of the Royal Statistical Society, 173(3): 631-656.

Brav, A., Graham, J.R., Harvey, C.R. \& Michaely, R. 2005. 'Payout policy in the $21^{\text {st }}$ century', Journal of Financial Economics, 77(3): 483-527.

Cassim, F.H.I. 2003. 'The repurchase by a company of its own shares: The concept of treasury shares', Stellenbosch Law Review, 120(1): 137-152.

Chivaka, R., Siddle, A., Bayne, L., Cairney, C. \& Shev, J. 2009. 'Reasons for share repurchases in South Africa: theory versus practice', SA Journal of Accounting Research, 23(1): 1-30.

Crotty, A. 2012a. 'JSE's lax disclosure regulations for share repurchases leave shareholders in the dark', BusinessReport [online]: URL:http://www.iol.co.za/business/businessnews/jse-s-lax-disclosure-regulations-for-share-repurchasesleave-shareholders-in-the-dark-1.1315665. Accessed 10 May 2013.

Crotty, A. 2012b. 'JSE proposes stricter disclosure rules', BusinessReport [online]: URL:http://www.iol.co.za/ business/business-news/jse-proposes-stricter disclosurerules-1.1414432 Accessed 10 May 2013.

Daly, K.J. 2002. 'Share returns of companies announcing share repurchases under a general authority.' Unpublished MBA research report, University of the Witwatersrand, Johannesburg.

Dittmar, A.K. 2000. 'Why do firms repurchase stock?' The Journal of Business, 73(3): 331-355.

Firer, C., Gilbert, E. \& Maytham, A. 2008. 'Dividend policy in South Africa', Investment Analysts Journal, 68: 5-20.

Grullon, G. \& Michaely, R. 2004. 'The information content of share repurchase programs', The Journal of Finance, 59(2): 651-680.

Hamman, W.D. \& Wesson, N. 2011. 'Disclosure of share capital: Are reporting standards clear?' Accountancy SA: February, 32-34.

Ikenberry, D., Lakonishok, J. \& Vermaelen, T. 1995. 'Market underreaction to open market share repurchases', Journal of Financial Economics, 39: 181-208.

Jagannathan, M., Stephens, C.P. \& Weisbach, M.S. 2000. 'Financial flexibility and the choice between dividends and stock repurchases', Journal of Financial Economics, 57: 355-384.

JSE (Johannesburg Stock Exchange). 2010. 'JSE listing requirements. Service issue no 13.' Johannesburg. LexisNexis Butterworths. [online]: URL:http://www.jse.co.za/How-To-List/MainBoard/Listing-requirements/JSE-listing-requirements.aspx. Accessed 4 August 2011.

Kahle, K.M., Dyl, E.A. \& Banyi, M. August 2005. 'Measuring share repurchases'. [online]: $U R L:$ http://ssrn.com/abstract=726284 or http://dx.doi.org/10.2139/ssrn.726284. Accessed: 5 December 2011.

Lintner, J. 1956. 'Distribution of incomes of corporations among dividends, retained earnings and taxes', American Economic Review, 46: 97-113.

Marsh, T.A. \& Merton, R.C. 1986. 'Dividend variability and variance bounds tests for the rationality of stock market prices', The American Economic Review, 76(3): 483-498.

RSA (Republic of South Africa). 1962. The Income Tax Act, No. 58 of 1962. Pretoria: Governmant Printer.

RSA (Republic of South Africa). 1973. The Companies Act, No. 61 of 1973. Pretoria: Governmant Printer.

RSA (Republic of South Africa). 1999. The Companies Amendment Act, No. 37 of 1999. Pretoria: Governmant Printer.

RSA (Republic of South Africa). 2008. The Companies Act, No. 71 of 2008. Pretoria: Governmant Printer.

International Accounting Standards Board (IASB). 2009a. $A$ Guide through International Financial Reporting Standards (IAS 1 Presentation of financial statements). London: IFRS Foundation Publications Department.

International Accounting Standards Board (IASB). 2009b. $A$ Guide through International Financial Reporting Standards (IAS 32 Financial Instruments: Presentation). London: IFRS Foundation Publications Department.

Stiglingh, R., Koekemoer, A.D., Van Schalkwyk, L., Wilcocks, J.S., De Swardt, R.D. \& Jordaan, K. 2011. Silke: Suid-Afrikaanse inkomstebelasting. Johannesburg: LexisNexis Butterworths.

Wainer, H. 2004. 'Consolidation of share incentive trusts touching a nerve', Accountancy SA, July: 12-13. 


\section{Appendix A}

\section{Companies included in the sample:}

Primary listing on JSE (35):

African Rainbow Minerals Ltd

Anglo Platinum Ltd

Anglogold Ashanti Ltd

Anooraq Resources Corporation

Assore Ltd

Bauba Platinum Ltd

Chrometco Ltd

Drdgold Ltd

Exxaro Resources Ltd

Firestone Energy Ltd

Gold Fields Ltd

Harmony Gold Mining Company Ltd

Impala Platinum Holdings Ltd

Infrasors Holdings Ltd

JCI Ltd

Jubilee Platinum Plc

Keaton Energy Holdings Ltd

Merafe Resources Ltd

Miranda Mineral Holdings Ltd

Mvelaphanda Resources Ltd

Northam Platinum Ltd

Optimum Coal Holdings Ltd

Pamodzi Gold Ltd

Petmin Ltd

Platfields Ltd

Royal Bafokeng Platinum Ltd

Sallies Ltd

Sentula Mining Ltd

Simmer And Jack Mines Ltd

South African Coal Mining Hldgs Ltd

Thabex Ltd

Village Main Reef Gold Min Comp Ltd

Wescoal Holdings Ltd

Wesizwe Platinum Ltd

Witwatersrand Cons Gold Resources

Secondary listing on JSE (18):

Anglo American Plc

Aquarius Platinum Ltd

Bhp Billiton Plc

Brc Diamondcore Ltd

Central Rand Gold Ltd

Coal Of Africa Ltd

Diamondcorp Plc

Eastern Platinum Ltd

Gold One International Ltd

Great Basin Gold Ltd

Hwange Colliery Company Ltd

Lonmin Plc

Pan African Resources Plc

Platmin Ltd

Resource Generation Ltd

Rockwell Diamonds Incorporated

Tawana Resources N1

Uranium One Inc 